\title{
DOI: 10.7596/taksad.v9i4.2912
}

Citation: Cherevko, K., Grabovska, O., Trakalo, O., \& Kalyn, R. (2020). Some Aspects of Baroque Music Performance: An Examination on Concert and Festival Life of Lviv, Ukraine. Journal of History Culture and Art Research, 9(4), 236-246. doi:http://dx.doi.org/10.7596/taksad.v9i4.2912

\section{Some Aspects of Baroque Music Performance: An Examination on Concert and Festival Life of Lviv, Ukraine}

\section{Kateryna Cherevko ${ }^{1}$, Oksana Grabovska ${ }^{2}$, Oleksandra Trakalo ${ }^{3}$, Ruslana Kalyn ${ }^{4}$}

\section{Abstract}

The purpose of the research is to determine the role, significance, and peculiarities of the performance of Baroque music in Lviv in the context of the development of historically informed performances as one of the leading performing areas of modern times. The methodology consists of a complex of scientific methods: source study, historical, theoretical, comparative, and empirical, which make it possible to identify the specific features of historically informed performance in Lviv. The scientific novelty is determined by the main aspect of the stated theme, its relevance and place in the structure of music theory and performing processes. The problem of the formation of the traditions of historically informed performance is studied based on the activities of well-known Lviv musicians - performers of early music, such as Anna Ivanyushenko, Lyudmila Kapustina, Taras Drak, Bozhena Korchynska, and others, as well as activity of groups "A cappella Leopolis", "Gardarica" and others who actively participate in international festivals of early music not only in Ukraine but also in European countries. For the first time, a panorama of the concert and festival movement of early music in the city of Lviv is outlined, which plays an important role in the formation of traditions of historically informed performance in the works of Lviv musicians and groups. As concluded, an interest in Baroque music of Lviv musicians has contributed to the emergence of a number of festivals and projects where Ukrainian and foreign performers have an opportunity to present works, adhering to the basic principles of historically informed performance. The performances of famous European musicians and conducting several master classes are becoming a significant factor in the formation of the traditions of historical performance in Lviv. The festival and concert life of Lviv and the creative activity of not only individual performers, but also creative groups determine the characteristic trends of the historically informed performance in the city of Lviv, which fully correspond to the leading tendencies of Western European performing arts.

Keywords: Musical performance, historically informed performance, musical festivals, concerts, master classes.

\footnotetext{
${ }^{1}$ Ph.D. in Art criticism, Associate Professor, Lviv National Music Academy named after Mykola Lysenko. ORCID ID: 0000-0001-5877-4429. E-mail: kcherev@gmail.com

2 Ph.D. in Art criticism, Associate Professor, Lviv National Music Academy named after Mykola Lysenko. ORCID ID: 0000-0003-2886-4903. E-mail: oksanagrabovska@icloud.com

${ }^{3}$ Ph.D. in Mathematics, Associate Professor, Lviv National Music Academy named after Mykola Lysenko. ORCID: 0000-0001-9006-6107.E-mail: moris26moris@gmail.com

${ }^{4}$ Ph.D. in Art criticism, Associate Professor, Lviv National Music Academy named after Mykola Lysenko. ORCID ID: 0000-0001-8345-3408. E-mail: ruslanakalyna@gmail.com
} 


\section{Introduction}

The history of the development of musical art of the $20^{\text {th }}$ - early $21^{\text {st }}$ centuries is a versatile period in terms of stylistic and genre manifestations. Musical performance as an integral part of the world music culture, on the one hand, is becoming a means of composers' new search, and on the other - of turning to the works of previous eras, recreating ancient traditions of their performance. Recently, performers have more and more often studied the works of the past in conditions of comprehensive immersion in the historical context. Thus, the leading trend in the performing arts of today is the "reconstruction" of the sounding of works in accordance with the aesthetic principles of the era in which they were created.

Western Ukrainian performing art, namely the art of the city of Lviv as one of the cultural centers of Ukraine, has its own, rather unique stylistic color, formed at the intersection of Western and Eastern influences, including such famous centers of musical performance as Vienna, Berlin, Munich, Krakow, Prague, and later, in the 50 s -70 s of the $20^{\text {th }}$ century, those of Leningrad (now St. Petersburg), Moscow, with world-renowned schools of masters. The multiculturalism of Lviv, created for centuries by Austrian, Lithuanian, Armenian, Polish, and Ukrainian spiritual-liturgical and secular musical culture, reflects the artistic panorama of the city. The deep historical ties of Lviv's music and performing arts with prominent western and eastern art centers and outstanding musicians of different historical epochs and styles, have determined the creative image and artistic level of the city, influenced the formation of artistic traditions on which performers of many generations were brought up. The study of the leading trends in the performance of early music in Lviv is what makes this research work relevant.

\section{Materials and methods}

The scientific approach to the diverse study of works of musical art of ancient times has contributed to the emergence of historically informed performance (Historically Informed Performance Practice - HIPP). The issues of historically informed performance are revealed in the works of a number of foreign and Ukrainian researchers: Harnoncourt N. (1987, 2019), Bowen J. (1993), Dolmetsch A. (1974), Nikolayevska Y. (2017), Sadovnikova I. (1998), Sikorska N. (2014), Simakova N. (2002), Chechenia K. (2010), Dodd J. (2015, 2020), Ravasio M. (2019), Hunter M. (2014), and others. Interviews with performing musicians and reviews of music critics on festivals and concerts are becoming an important source of information. The musical art of the Baroque era became the most significant in the study of historically informed performance. This is confirmed by the interest not only in baroque works but also in the basic principles of their authentic performance.

Therefore, the aim of the research is to determine the role, significance, and peculiarities of baroque music performance in the city of Lviv in the context of the main tendencies in the development of historically informed performance as one of the leading performing trends of modernity.

Scientific novelty is determined by the main perspective of the stated subject, its relevance and place in the structure of musicological and performing processes. The problem of formation of traditions of historically informed performance is studied on the basis of the activity of Lviv`s wellknown musicians - performers of early music, such as Anna Ivanyushenko, Lyudmila Kapustina, Taras Drak, Bozhena Korchynska, and others, as well as activity of groups "A cappella Leopolis", "Gardarica" and others who actively participate. in international festivals of early music not only in Ukraine but also in European countries. For the first time, a panorama of the concert and festival movement of early music in the city of Lviv is outlined, which plays an important role in the formation of traditions 
of historically informed performance in the works of Lviv musicians and groups.

The methodology of the research is determined by the specifics of the problem and consists of a complex of scientific methods: source study, historical, theoretical, comparative, and empirical, which make it possible to identify the specific features of historically informed performance in Lviv.

\section{Results and Discussion}

Interest in music of the Baroque era is not a new trend, because, since the $19^{\text {th }}$ century, artists have discovered for themselves the music of the past through the search and republishing notes, studying the biographies of composers, and performing their works. The first example of historically informed performance in Europe is the production of "St Matthew Passion" by J.S. Bach in 1829, which was performed under the direction of F. Mendelssohn-Bartholdy in Berlin. However, authentic performance became most widespread due to the activities of ensembles of early music, among which the most famous is "Concentus musicus Wien". Thus, since the ensemble was founded in 1953 by the outstanding conductor N. Harnoncourt, historically informed performance has been actively developed.

Today, authentic performance is an important component of the performance process; however, it has its own peculiarities. Based on modern theoretical research, we can consider historically informed performance in the context of aesthetics of today's world music art.

The aesthetic preconditions for turning to the music of previous epochs are conditioned by the very process of the development of modern musical art. N. Harnoncourt (2019) notes, "The radical change in the role of music has been evolving increasingly over the last two centuries. Closely related to this is a change in attitudes towards contemporary music, as well as art in general: as long as music was an integral part of life, it reflected the modernity of that time. It was a living language for the story of the unspeakable and could be understood only by the contemporaries..." (p.7-8).

The changing role of music in modern society has contributed to the growing interest in early music. Russian researcher N. Simakova (2002) notes that "Turning to it (early music - K.Ch.) is not just a tribute to the high cultural values of the past, but also the result of the spiritual needs of a presentday person... Undoubtedly, the performance of early music became possible due to the success of musical science of the $20^{\text {th }}$ century, namely the publication of new scientifically verified music note editions, thorough musicological research" (p.3).

It is interesting how present-day audience describe their feelings caused by the music of previous eras, "Music penetrates us by itself, bypassing the brain and everything rational we have.... The listener is present at its return because the performance is like magic and is similar to the revival of the Phoenix, the process of reviving sounds from the ashes of the notes recorded on paper in the heavens of human souls. Ideally, we should simply give ourselves to music as it flows and believe that it will bring us to where we deserve and quench the thirst we feel. Baroque music, in contrast to modern, rhythmic one, does not take up right away, it takes time to become filled with it. On the other hand, it does not let go for a long time either, even formally, when it has already sounded in the hall" (Kasyanenko, 2016). It is not surprising that the music of previous eras makes up a big part of today's concert programs.

The popularity of early music has led to the formation of different approaches to its presentation, the first of which is the use of modern performing techniques and instruments, and the second is its musical and stylistic understanding in relation to the time in which it was created and using corresponding authentic instruments. The most popular at the turn of the $19^{\text {th }}-20^{\text {th }}$ centuries 
was the second way in which music was presented as authentically as possible, in the manner of performance and sounding that was characteristic of that era. As is well known, the first thorough work containing a theoretical understanding of authenticity belongs to the British musicologist, master of manufacturing of ancient instruments Arnold Dolmetsch (1858-1940). His work "The Interpretation of the Music of the Seventeenth and Eighteenth Centuries" laid the foundations for the practical mastery of music of previous eras (Dolmetsch, 1974).

However, the term "authenticism" was criticized by a prominent performer of early music, Dutch harpsichordist, organist, and conductor Gustav Leonhard, who believed that only the subject could be authentic, but not the performance of the work, because it is impossible to go back into the past. Therefore, the term "authenticism" has been replaced by the definition of "historically informed performance" (HIP), which is closer to the context of contemporary performance of early music and contains features of an innovative approach to the music of the past.

Matteo Ravasio characterizes historically informed performance basing on the leading trends in the development of general philosophy of music. He argues that modern musicology characterizes historically informed performance as "... (1) compliance-focused, as opposed to interpretationfocused; (2) impersonal and objective, as opposed to personal and creative, and (3) work-centered, as opposed to practice-centered. I examine these features in turn" (Ravasio, 2019, p. 194).

Julian Dodd (2015) identifies two components of the authenticity of performance, namely compliance authenticity and interpretive authenticity. Compliance authenticity is based on strict adherence to the instructions contained in the score. However, there is another approach to performance, which uses elements of interpretive authenticity that allow you to convey the content more deeply and convincingly.

Thus, an important problem of authentic performance is the ability to interpret the original note text. This applies to cases where the work is written in the ancient form of notation. So, the ability of the performer to "create" music using special methods of note record becomes determinative. Such methods include the ability to decipher digital bass, determine the cast and their number, etc. A deep knowledge of the performing techniques of that era, namely strokes, agogics, dynamics, articulation, the ability to choose the right tempo, adjust instruments, and most importantly, being able to improvise and properly ornament the musical text are important in the performance of early pieces.

Therefore, when performing works of past epochs, the question arises as to the depth of historical awareness. Analyzing the words of American researcher Mary Hunter, "Historically informed" and "historically aware" are terms that ... indicate performance practices and attitudes that directly or indirectly rely on documentary sources from the time of the work to inform interpretative decisions about the acoustic, conceptual, and (in the case of opera) visual environment in which a work was originally created" (Hunter, 2014, p.606; see also Ravasio, 2019, p.193), Julian Dodd (2020) concludes that "...performance of a work is historically informed insofar as it exemplifies a style of music making that would have been seen as appropriate for the work's performance during the period within which the work was composed" (p. 85). Thus, the historically informed practice of performance is aimed at working on the score; however, there is another approach to the sound realization of the work, which focuses on its "recomposition" in terms of stylistic and sound features of the era. Ravasio (2019) uses the term "nonwork performances" and describes it as "performances that are based on general guidelines agreed upon by musicians who are competent in a given musical tradition" (p. 202).

Thus, this practice of performing works contributed to the formation of certain performance approaches, which are aimed at conveying the style of the era, the specifics of sound and performance 
style. First of all, for a historically informed performance, the presentation of a musical notation is not a guarantee of successful realization of the work. Julian Dodd (2020) notes that when performing compositions of the past, "... performers can be true to a work, not merely by obeying its score, but by performing it in a manner that evinces understanding of it" (p. 86). However, there is another difficulty in the performance, associated with the method of notation of the score itself, which may contradict its modern musical notation, and hence the sound. Dodd also points out that "when such normative conflict arises, performers can be justified in trading some notational accuracy for the sake of making their performance more interpretively authentic" (Dodd, 2020, p. 86).

At the present stage of development of historically informed performance, we can note the close interaction of performance and musicology, which have a common goal - to recreate the "authenticity" of musical compositions of previous eras. At the same time, representing baroque works, performers often turn to a number of theoretical works of musicologists, revealing both the stylistic principles of baroque works, and genre and formative ones. "Musicological knowledge is not an end in itself. It should give us only the means to improve the quality of performance, because it is really in line with the concept, and it will be authentic only when the work gains its clearest and most beautiful expression" (Harnoncourt, 2019, p.13-14).

Thus, the performance of works belonging to another historical epoch is a rather complex process that requires from the musician-performer not only understanding the philosophical and aesthetic principles of that epoch, but also the ability to correctly convey the figurative and stylistic features of the work. Therefore, we can identify several prerequisites for the performance of such works. An important component in the preparation of a work for performance is a certain research work, which includes the study of not only theoretical works dedicated to the epoch, but also listening to works by various composers belonging to that historical period. After all, the performance of works of any of the previous eras and their free interpretation leads to the loss of the possibility to approach the historically authentic sound. Therefore, preliminary research work and acquaintance with the existing research create a strong enough basis for the next steps towards success in the field of historically informed performance. As a result of this approach, the characteristic style features inherent in the epoch are identified. Knowledge of the history of writing the work allows you to understand not only its purpose (spiritual work or secular), content, figurative world, but also the acoustic features that are necessary for the authentic reproduction of the sound of the work. We mean the specifics of the structure and acoustic capabilities of the instruments of that time, which differ from modern ones not only in structure but also in playing technique. Therefore, performers, trying to reproduce the sound of the works as closely as possible, often turn to mastering the technique of playing authentic instruments. The difficulty of the performance also lies in the peculiarity of the unusual combination of the sound of different instruments, because the ensemble performance creates a specific and unique acoustic atmosphere, through which the perception of the figurative world of the work occurs. Special attention should be paid to vocal-instrumental works, in which not only the timbre of the voice is important, but also the principle of sound formation and the manner of performance. Important components of historically informed performance are the peculiarities of the interpretation of the means of expression - the tempo, dynamics, observation of phrasing, etc.

Therefore, on the way to the return of early music to a full-fledged artistic life today, it is important to actively implement it in the educational and pedagogical process. After all, there is a need to educate specialists - performers using old instruments, specialists in expert evaluation of instruments, restoration, repair, and making copies. It is also necessary to train art critics to prepare for printing manuscripts, reprints, facsimiles, as well as to edit music publications with performance 
recommendations.

And, if the peak of fascination with early music in Western European countries has already passed, in Ukraine the musical baroque constantly gathers full auditoriums. Therefore, we can observe the animation of the music-festival movement, which led to the creation of a number of festivals of early music in different cities of Ukraine. These festivals are becoming a kind of "laboratories", where not only the acquaintance with the musical works of the Baroque era takes place, but also the exchange of certain performance and style traditions. Such music festivals have, as a rule, the status of international ones, so they often host performances by foreign groups, demonstration lectures, presentations, and master classes. Based on the performance practice provoked by increasing interest in baroque works, we can identify several leading trends in authentic performing arts, namely, the revival of old instruments, the creation of specialized groups of early music, including individual baroque works in modern concert programs, holding contests of early music performers and comprehension of musical stylistics of works in a number of theoretical works.

At the beginning of the $20^{\text {th }}$ century, several festivals of early music appeared in Ukraine, which take place in different cities: in Sumy (Bach-fest), Chernihiv (Art project "Old music in the old city"), and Lviv. Whereas at the Festival of Early Music in Lviv, in the early 2000s, these were only rare echoes of European traditions (the founder and organizer Roman Stelmashchuk, 2003), today it has become a tradition because the festival hosts master classes, concerts of leading European performers, resulting in an exchange of experience. In addition, many Ukrainian musicians attend festivals abroad and study at leading European music institutions.

As mentioned above, historically, Lviv has organically intertwined the achievements of Eastern, Western cultures and Ukrainian art, represented by the diversity of cultural traditions and stylistic trends of different eras. A striking example of this is the annual thematic names of the festivals - "Lviv is 750" (2006), "Since the Hetmanate" (2009), "Musical Lviv and the Habsburg Heritage" (2010), "Praise to Music or Lviv Ceciliada" (2012), "From Above the Banks of the Danube" (2014), etc.

Roman Stelmashchuk, a Ukrainian musicologist, composer, and founder of the "A cappella Leopolis" ensemble and the Lviv Festival of Early Music, said, "A modern listener and an artist have many points of access in common with early music, while the principles of improvisation, scoring of vocal melodies with the use of instruments, etc. are attractive in the instrumental music of the Renaissance ..." (Segin Bogdan, 2016). As a result, new projects are emerging today, in which Renaissance and Baroque vocal and instrumental music is performed. The initiators of these projects are Lviv musicians Anna Ivanyushenko, Bozhena Korchynska, Lyudmyla Kapustina, and Taras Drak.

Anna Ivanyushenko is a lecturer at the Piano Department of the Lviv National Music Academy named after M. Lysenko, she conducts courses in the history of piano art and the practice of performing basso continuo for masters. At the same time, she is the founder of the baroque orchestra of the academy cappella. In his review of one of the concerts of the Bach-fest, namely the performance of Anna Ivanyushenko, Igor Kasyanenko notes, "Her harpsichord sounds emotional, which is rare for an instrument that does not have forte or piano. And up to date, that is, this music is alive, relevant, not illustrative, historical" (Kasyanenko, 2016).

A unique concert called "Authentic Baroque" took place on May 23, 2018, with the participation of Anna Ivanyushenko as a harpsichordist. Besides her, the concert Konstantin Yakovlev, a leading Russian performer of Baroque and Renaissance music, who plays the bassoon and oboe copies of the $17^{\text {th }}-18^{\text {th }}$ centuries instruments, took part in the concert; Lesya Dermenzhi, a Lviv violinist who plays an instrument with catgut strings and a bow of an ancient shape; Natalia Pavliv, who plays 
the recorder, the sound of which also differs significantly from the usual flute, and Dmitry Nikolayev the cello. In such an unusual composition, the musicians performed works by Vivaldi, Corelli, Handel, Telemann, and Fasch. As the head of the baroque cappella, A. Ivanyushenko invites specialists in the field of historically informed performance to Lviv for cooperation, for conducting specialized master classes in particular. As a result of such cooperation, the orchestra was lucky to play with famous violinists Oleksandr Pilchen, Radoslav Kamenyazh, conductors Marek Toporovsky, Bohdan Shved, and Nazar Kozhukhar. Thanks to Haliciana Scola Cantorum organization, students performed at concerts with Swiss gambist Brian Franklin and singer Tatiana Polt-Lutsenko, as well as participated in the international project Open Opera Ukraine, including the production of the first baroque opera "Dido and Aeneas" in Lviv and Kyiv. Interestingly, the musicians performed works on reconstructed instruments with catgut strings.

The art director of the Festival of Early Music in Lviv, leader of the ensemble "A cappella Leopolis" Lyudmila Kapustina and the group performed at numerous festivals of early music not only in Ukraine but also abroad, and recorded several compact discs. L. Kapustina has repeatedly participated in international courses in the interpretation of early music and conducted the course "Ukrainian Orthodox music and Its Performance" at the Festival of Early Music in Stary Sącz (Poland, 2004).

The founder of several early music groups is Taras Drak, a Lviv musician. Among them are the association of musicians "Lviv Music Workshop", which performs music of the $13^{\text {th }}-17^{\text {th }}$ centuries, ensemble "Rukavy" ("The Sleeves") (Kyiv, 1992), the Renaissance choir "Res Publica" (St. Petersburg, 1994), the ensemble of medieval music "Laterna Magica "(St. Petersburg, 1998), the Renaissance ensemble "Vita Nova " (Lviv, 2004) and "Dance Of Renaissance " (St. Petersburg, 2006).

Performer-virtuoso Bozhena Korchynska is the popularizer of the Ukrainian longitudinal flute (chromatic flute), the creator of a new style of playing the Ukrainian chromatic flute, the initiator, and co-author of a new model of the chromatic flute. She is one of the main promoters of the Ukrainian pipe sopilka in Europe, where this instrument remains virtually unknown to this day. It is worth noting that in the Baroque era, the sopilka was used as both a solo and ensemble orchestral instrument. In addition, $B$. Korchynska is an interpreter and researcher of music of the $17^{\text {th }}-18^{\text {th }}$ centuries, the founder of the project "The Baroque Mirror of Lviv". I. Kasyanenko describes her manner of performance in quite an interesting way, "Bozhena Korchynska ... looks in outward appearance deliberately detached from the audience and is entirely devoted to the process of presenting the ancient sound of the performed work as accurately as possible. She is communicating with the listeners only through sounds and pauses" (Kasyanenko, 2016).

The next on the way to popularize the recorder was this year's festival "Music in Old Lviv", which took place on August 30, 2020. In the online broadcast of the concert, which took place in the concert hall of the Lviv Philharmonic, the works of European composers were performed by the ensemble: Natalia Pavliv (Ukrainian longitudinal chromatic flute), Olga Milosta (Ukrainian longitudinal chromatic flute), Bohdan Kravchenko, (Ukrainian longitudinal chromatic flute), Maria Bil' (cello) and Anna Ivanyushenko (harpsichord). Among the works of the Baroque era were the Quartet for 3 flutes and basso continuo from the cycle "Tafelmusik" by Georg Philippe Telemann, Trio-sonata No.6 for two flutes and basso continuo in $\mathrm{G}$ major, op. 2 by Joseph Boden de Bouamortier. Trio-sonata "La Follia" for two violins and basso continuo in D minor, RV 63.

A significant event in the process of forming the traditions of historically informed performance was the $15^{\text {th }}$ Festival of Early Music "Lviv's Mirror: Multiculturalism of Lviv through the Eyes of 
Musicians" which was held in 2017. The festival presented an extremely wide panorama of works of early music - from medieval Gregorian chant to anonymous choral concerts. Thus, Jewish synagogue music of the 16th-17th centuries, performed by the vocal ensemble "A cappella Leopolis", was presented at the festival. Within the framework of this project, a concert "Music of the 16th-17th centuries in Poland and Lithuania" was held, where a musician from Lithuania Dalius Klisis presented a Lithuanian wind instrument birbine - a national version of the clarinet. Armenian liturgical chants were performed by the liturgical choir of the Armenian Cathedral "Sagmos" under the direction of Protopsalt Andriy Shkrabyuk.

The concert "Musical Images of Lviv of the 16th-19th Centuries" also featured early romantic works by Franz Xaver Wolfgang Mozart performed by Mariana Laba (soprano), O. Rapita and M. Drahan (piano). A year earlier, on June 30, 2016, Franz Xaver Mozart's Concerto for Piano and Orchestra was performed in the framework of the festival by O. Rapita (piano), S. Velyanyk (conductor), and the Academic Symphony Orchestra of the Lviv Philharmonic.

Let us note another trend that is visible in the festival movement of early music - the synthesis of religious and folk traditions. Interest in Ukrainian church music, in the works of Ukrainian composers, professional groups, and a wide circle of Ukrainian church singing admirers is manifested largely through ethnography, through the folk song basis as an expression material in polyphonic church music.

Since the very beginning of its history, Lviv has been the center of many religions, which influenced the culture of the city in general, including music one. Orthodox, Latin-Catholic (Roman, and later Byzantine-Greek - Eastern rite), as well as Protestant, Jewish, etc., traditions intersected here. Today the situation is also exceptional - Greek Catholic, Roman Catholic, Orthodox - the Kyiv Patriarchate and the Ukrainian Autocephalous Church, the Armenian Cathedral church coexist in the city. A multinational, multi-confessional, multicultural city has a special atmosphere, in which the traditions of East and West are manifested. In the Orthodox, and later in the Greek Catholic churches, choral (monodic or polyphonic), solo (priest, deacon), and mostly antiphonal, ie alternating performance was heard. Instrumental music was used mostly in official working events of the Lviv magistrate, city council. For a long time, the Roman Catholic Church did not introduce instrumental music in liturgical performance. Nevertheless, at the beginning of the 15th century, organ was already heard in some Lviv churches.

There are several reasons to consider the performance of church music in the context of historically informed performance. First of all, because the purpose of the performance is to renew the lost traditions of singing. Works are not interpreted by the bearers of ancient traditions, but by performers who study the peculiarities through theoretical explanations and practical classes. Not only the sound itself is reproduced, but also the conditions of performance, the acoustics of the room, items of the interior, which is aimed at reproducing the atmosphere of the Baroque era.

The revival of Ukrainian baroque music took place in the 1990s and is associated with the performance of choral concerts. This became the guideline of the ensemble "A cappella Leopolis". In the records of the group of different years, there are CDs "Side Adam pryamo Raya ("Adam sat before Paradise") / 12-voice choral concerts of the first half of the $18^{\text {th }}$ century." (UkrMusic, 2007), "Snachala dnes' poutru rano ("Today, early in the morning) / Song sketches from Ukrainian antiquity" (Lida, 2009), "Requiem Liturgy and other works by Mykola Diletsky / From newly discovered music manuscripts" (Nash Format, 2014).

In addition, the ensemble "A cappella Leopolis" participated in the recording of the CD "Musica 
Claromontana - Jasnohorska Early Music from Czestochowa" in Warsaw (DUX: Warsaw, 2007). For the triple mixed choir, the concert "Vek moy skonchavaetsya" ("My time is coming to an end") was recorded, which comes from the Kirill Turovsky`s Public Prayer Canon. Four parts of treble, tenor, and bass are involved in the recording; solo parts are led by "low" ensembles of voices - basses and tenors. The eschatological theme of the work is permeated with penitential motives.

The project "Snachala dnes' poutru rano..." ("Today, early in the morning...") was presented by the vocal ensemble "A cappella Leopolis" at the Festival of Early Music in Lviv on June 17, 2018. The program originally implemented the idea to use the genre of chant. The concert is united by a common plot line with some elements of theatrical action (lyrics read by Taras Grudovy), full of instrumental music with the use of authentic instruments combined with a cappella singing. Ukrainian folk instruments - bandura (Dmytro Gubyak) and pipe (Olga Milosta, Bohdan Kravchenko) were also involved in the project under the direction of its organizer Lyudmila Kapustina. Back in 2009, the ensemble "A cappella Leopolis" recorded the disc "nachala dnes' poutru rano... ("Today, early in the morning...") / Song sketches from Ukrainian antiquity."

At the concert dedicated to the memory of the founder of the Festival of Early Music in Lviv Roman Stelmashchuk, on June 27, 2016, old Catalan Marian songs "The Red Book of the Black Madonna" performed by the medieval music ensemble "Gardarica" of the Lviv Music Workshop (Ukraine - Russia) composed of Irina Dubrova, Victoria Titarova, Kateryna Kyselyova, Vadim Weinstein, Taras Drak. "The Red Book of the Black Madonna" is an anonymous musical opus, a hymn of praise to Virgin Mary, which includes three caccia, four virelai, a ballad, a motet, and a dance of death. In addition to singing, the performance includes the lute, bells, tar, fidel, hit tern, fidel, organetto. The manuscript "Llibre Vermell de Montserrat", presented on 172 pages, is devoted to the statute of the monastery of Montserrat with detailed rules of life, economic directives, accounts. A note record of ten musical works for $1-3$ voices was found in the manuscript. The Codex was completed and bound in red cover in 1399.

One of the pressing issues of today is the issue of creating a correct interpretation of the works of the Baroque era, it deals with both vocal and instrumental authenticity. Within the direction of historically informed performance, which emerged at the end of the $20^{\text {th }}$ century, the tradition of providing consultations and conducting master classes by foreign specialists has become permanent in Lviv: European musicians come, exchanging experience of performing on authentic instruments. Ukrainian-Swiss conductor Bohdan Shved (Basel, Switzerland), in the series of artistic events "The Baroque Mirror of Lviv" (November 13, 2018), taught the fundamental principles of baroque music interpretation stylistics, vocal ornamentation and correct vocal pronunciation of German texts, combination and balance of instrumental timbres.

The legendary Polish musician, one of the founders of historical performance in Poland, harpsichordist, organist, conductor and composer, teacher, founder of the Museum of Historical Claviers Fortepianarium Marek Toporowski conducted a master class with Krzysztof Firlus, a gambist and double bassist, laureate of prestigious international competitions, who devoted his classes to old techniques of playing the bowed string instruments of the bass group - viola da gamba, baroque cello, and double bass. Works by G. Telemann, F. Couperin, K. Abel, and F. Antoine were performed by Marek Toporowski and Krzysztof Firlus at the concert "Noble Passion of Baroque".

In May 2019, the Polish pianist Katarzyna Drogosz first brought to Lviv a historical piano of the Mozart era (a copy of Andreas Stein's instrument of 1780). Katarzyna Drogosz is one of the few pianists who has dedicated herself to performing on historical claviers, to researching the history and structure of 
varieties of old keyboard instruments of the 17th - early 19th centuries. Among the concerts that promote Ukrainian music at the Festival of Early Music in Lviv there were interesting projects called "On the Cossack Ways", where works were performed by Dmytro Hubiak (bandura), and "Ukrainian Music in the Palaces of the Empire" performed by Bozhena Korchynska (flute) ) and Svetlana Shabaltina (harpsichord).

Besides, a significant event in Ukraine is the annual Italian baroque music festival "Italia festival Barokko", founded in 2014, which is held in different cities of Ukraine, namely, in Kyiv, Odesa, Mariupol, Chernivtsi, and Lviv. This festival is a joint Italian-Ukrainian project under the artistic direction of Nancy Milezis Romano. The leading cultural and academic institutions of Ukraine are involved in its organization.

In his article, dedicated to the festival, Ukrainian musicologist Yuriy Chekan notes, "World practice puts a task of a fundamentally different level before modern musicians: it is about the so-called authentic or historically informed performance. The work should sound the way it sounded at the time of its creation: using the instruments of that time, recreating the atmosphere inherent in the practice of the $17^{\text {th }}-18^{\text {th }}$ centuries. The romantic narcissistic artist, who seeks to show himself first, has been replaced by a researcher who reproduces the subtlest details of the sound of the past, reconstructs the worldview recorded in music, separated by centuries from us. At the same time, the sounding does not become a boring museum exhibit. It lives, breathes, inspires, because it talks about what has always worried the Homo sapiens - about life and death, about the tragedy of transient time and the joy of life-giving love, about honor and betrayal, about the beauty of the soul and suffering for the faith "(Chekan, 2014).

As part of the "Italia festival Barokko" festival, on October 15, 2019, a concert "Sweet Sufferings" took place in the Mirror Hall of the Solomiya Krushelnytska Lviv National Academic Opera and Ballet Theater. The program of the concert consisted of cantatas on love themes by A. Stradella, J. Bononcini, G.F. Handel, F.P. Cipriani, J. A. Brescianello, performed by musicians from Italy - the ensemble "La Liradi Orfeo", Raffaele Pe (counter-tenor), Andre Lislevand (viola da gamba), and Giacomo Pinardi (archilute).

The leitmotif of chamber music is one of the main trends that accompanies the festival atmosphere of early music in Lviv. It is initially manifested in small old concert halls, where musical and aesthetic tastes of listeners of different social and national environments are formed: cathedrals, museums, art institutions and courtyards of Lviv, the House of Organ and Chamber Music, the Lviv National Philharmonic and the Mirror Hall of the S. Krushelnytska Lviv National Academic Opera and Ballet Theater.

\section{Conclusions}

In short, an interest in baroque music by Lviv musicians has contributed to the emergence of several festivals and projects where Ukrainian and foreign performers have the opportunity to present their works, adhering to the basic principles of historically informed performance. Historically informed performance requires a much deeper immersion in both the stylistic and performance principles of the era. One of the problems of historically informed performance is the problem of notation, namely, its correct reproduction by modern means of notation. The performances of renowned European musicians and conducting a number of master classes are becoming a significant factor in the formation of the traditions of historical performance in Lviv. The festival and concert life of Lviv and the creative activity of individual performers and groups determine the characteristic trends of historically informed performance in Lviv, which fully correspond to the leading tendencies of Western European performing arts. 


\section{References}

Bowen, J. A. (1993). The History of Remembered Innovation: Tradition and Its Role in the Relationship between Musical Works and Their Performances. The Journal of Musicology, 11(2), 139-173. https://doi.org/10.2307/764028

Chechenya, K. (2010). Questions of authenticity in music (theory and practice) Art notes: Collection of scientific papers the National Academy of Management of Culture and Arts, 18, 16-23. Kyiv: Milenium.

Chekan, Yu. (2014, November 11). Ukraine is Europe! The political slogan acquired special significance and sound during the First Music Baroque Festival. Retrieved from https://day.kyiv.ua/uk/article/kultura/ukrayina-ce-ievropa

Dodd, J. (2015). Performing Works of Music Authentically. European Journal of Philosophy 23, 485508. https://doi.org/10.1111/j.1468-0378.2012.00546.x

Dodd, J. (2020). Blurred Lines: Ravasio on "Historically Informed Performance". Journal of Aesthetics and Art Criticism, 78(1), 85-90. https://doi.org/10.1111/jaac.12710

Dolmetsch, A. (1974). The Interpretation of the Music of the Seventeenth and Eighteenth Centuries. Seattle and London: University of Washington Press.

Harnoncourt, N. (1987). Music in the language of sounds, the way to a new understanding of music. Moscow: Muzyka.

Harnoncourt, N. (2019). Baroque music. Ways to new understanding. (O. Koval Trans.). Moscow: group of companies "RIPOL-klassik"/ "Pal’mira".

Hunter, M. (2014). Historically Informed Performance. In Helen M. Greenwald (Ed.), The Oxford Handbook of Opera. (pp. 606-626). Oxford University Press.

Kasyanenko, Yu. (2016, November 09). In Sumy, the Bach festival was completed by a trio from Lviv. Retrieved from http://creativpodiva.com/posts/53763

Nikolayevska, Y. (2017). The authentic performing strategy and its modern transformations. Aspects of historical musicology, 10, 180-198. Retrieved from http://nbuv.gov.ua/UJRN/asismy 20171015

Ravasio, M. (2019). Historically Uniformed Views of Historically Informed Performance. The Journal of Aesthetics and Art Criticism, 77(2), 193-205. https://doi.org/10.1111/jaac.12632

Sadovnikov, Yu. (1998). College of Early Music: seven years. Early music, 1/1998, 2-4.

Segin Bogdan (2016, June 30). Interview with Roman Stelmashchuk (June, 2014) [Video]. YouTube. https://www.youtube.com/watch?v=G8WYxPk1SSE

Sikorska, N. V. (2014). The main aspects of performing in Baroque style: the experience of generalization from the point of view of contemporary science and practice. Scientific Bulletin of the National Music Academy of Ukraine named after P. I. Tchaikovsky: Early music - a modern dimension, 109(6), 96-116.

Simakova, N. A. (2002). Vocal genres of the Renaissance. Moscow: Moscow P. I. Tchaikovsky Conservatory. 